\title{
Soil aggregation may be a relevant indicator of nutrient cation availability
}

\author{
Léa Bedel ${ }^{1,2} \cdot$ Arnaud Legout $^{1}$ (D) - Anne Poszwa ${ }^{2} \cdot$ Gregory van der Heijden $^{1} \cdot$ Mélanie Court $^{1}$. \\ Noémie Goutal-Pousse ${ }^{3} \cdot$ Emmanuelle Montarges-Pelletier $^{2} \cdot$ Jacques Ranger $^{1}$
}

Received: 8 January 2018 / Accepted: 13 November 2018 / Published online: 14 December 2018

(C) INRA and Springer-Verlag France SAS, part of Springer Nature 2018

\begin{abstract}
- Key message Aggregation was studied in two acidic forest soils (NE France) to investigate the potential link between available $\mathrm{Ca}$ and $\mathrm{Mg}$ content and soil aggregate size distribution and properties. Clay content influenced the aggregation status while clay mineralogy influenced aggregate stability and dynamics. Aggregation status and reactivity of soil components contributed to the difference of exchangeable $\mathrm{Ca}$ and $\mathrm{Mg}$ content in topsoil between the two sites.

- Context Though nutrient fluxes are important to define forest soil chemical fertility, the quantification of nutrient reservoirs in the soils and their availability to tree uptake is essential. A thorough understanding of nutrient availability requires an investigation of nutrient location and distribution in the soil solid phase.

- Aims The general aim was to investigate the potential link between available $\mathrm{Ca}$ and $\mathrm{Mg}$ content and soil aggregate size distribution and their properties (chemical, physical, mineralogical).

- Methods Soil aggregates were separated according to three size classes (200-2000 $\mu \mathrm{m} ; 50-200 \mu \mathrm{m} ;<50 \mu \mathrm{m})$ in two forest soils of the Lorraine plateau (France), both classified as Luvisols ruptic. The physical, chemical, and mineralogical properties were measured for each aggregate class.

- Results We showed that the relative abundance of an intermediate aggregate class [200-50 $\mu \mathrm{m}$ ] was relevant to explain the difference of exchangeable $\mathrm{Ca}$ and $\mathrm{Mg}$ between sites. These aggregates were the poorest in organic and reactive mineral components and were unstable, which may mitigate the retention of $\mathrm{Ca}$ and $\mathrm{Mg}$ by ion-exchange.

- Conclusion This study highlights the role of aggregation and reactivity of soil components as relevant determinants of cation availability to tree uptake in soils.
\end{abstract}

Keywords Chemical fertility $\cdot$ Calcium $\cdot$ Magnesium $\cdot$ Forest soil $\cdot$ Aggregation

\section{Introduction}

Assessing the chemical fertility of soils and its role in the sustainability of forest ecosystems remains a challenge, in

Handling Editor: Ana Rincón

Electronic supplementary material The online version of this article (https://doi.org/10.1007/s13595-018-0782-y) contains supplementary material, which is available to authorized users.

Arnaud Legout

arnaud.legout@inra.fr

Inra, BEF, F-54000 Nancy, France

CNRS, LIEC, Université de Lorraine, F-54000 Nancy, France

3 ONF, Département RDI, F-54600 Villers-lès-Nancy, France particular for forests developed on nutrient-poor acidic soils. The measurement of available and total nutrient reservoirs through ion-exchange and dissolution techniques is necessary, but nutrient fluxes and cycling are also relevant components of the chemical fertility of forest ecosystems (Legout et al. 2014). Understanding nutrient cation availability in the ecosystem and in the soil, in particular, is therefore of paramount interest.

The status of nutrient cations in soils (e.g. "free" in solutions, adsorbed on reactive solid surfaces, belonging to solid organic or mineral structures) determines their "potential" lability and their availability for uptake by plants. Their actual availability is, however, complex to assess and depends on many factors including soil structure. In soils, organic compounds, clay minerals, iron $(\mathrm{Fe})$, and aluminum $(\mathrm{Al})$ oxides form organo-mineral associations which cement soil particles 
of all sizes to form soil aggregates (Andreux et al. 1980; Bronick and Lal 2005). The bonding and arrangements (protection and coating) of soil particles determine the accessibility of nutrient cations sources and, therefore, their actual availability. The availability of an element adsorbed on reactive surfaces, but trapped in very stable aggregates, is for instance far lower than if it is situated on more accessible reactive surfaces (Girard et al. 2011).

Hence, the availability of nutrient cations in the soil is related to the stability of soil aggregates, which is thought to be proportional to their size (Balesdent et al. 2000; Oades and Waters 1991; Oades 1984; Schmidt et al. 2011) and related to soil organic matter (SOM) stability. SOM stability is inversely related to the size of aggregates where it is trapped: the carbon in the largest aggregates is the most labile, while carbon trapped in the finest aggregates is expected to be more stable (Andreux et al. 1980; Balesdent et al. 1998; Jolivet et al. 2003; Schmidt et al. 2011). The so-called humic substances are less represented in the macro-aggregates while they dominate the organic fraction of the micro-aggregates (Berthelin et al. 1999).

Different methods may be used to study the aggregation status of soils (i.e. the properties and abundance of different aggregate size classes). Studies which were mainly carried out on agricultural soils (Andreux et al. 1980; Balesdent 1996; Balesdent et al. 1998, 1991; Jolivet et al. 2003; Bronick and Lal 2005) used mechanical treatments to separate aggregate size classes in order to characterize their impact on carbon and nutrient availability. Usually, only the soil upper horizons from 0 to $20 \mathrm{~cm}$ were taken into account, and energetic treatments are required to separate the very stable fraction of aggregates in cultivated soils. Aggregate fractionation studies carried out on organo-mineral horizons $[0-20 \mathrm{~cm}]$ have been mostly used for detailed SOM studies (Adesodun et al. 2007; Andreux et al. 1980; Balesdent et al. 1998; Britzke et al. 2012; Jolivet et al. 2003; Kuhn et al. 2012; Leguédois and Le Bissonnais 2004; Qin et al. 2010; Stemmer et al. 1998). Investigations on other components, especially minerals, remain scarce (Adesodun et al. 2007). To our knowledge, no such study has been carried out on whole soil profiles, and rarely on forest soils (Fernández-Ugalde et al. 2013). Unlike agricultural soils which are subjected to frequent disturbance through cultivation and inputs of fertilizers and lime, forest soils may remain undisturbed for many decades. Further research on aggregation status in forest ecosystems is thus required to assess its role on nutrient cation availability to tree uptake.

We believe that a better understanding of nutrient cation availability in soils could be achieved through a detailed investigation of their location and distribution in the different aggregate size classes. The specific objectives of this study were to (i) describe the aggregation status and characterize the different aggregate classes found and (ii) investigate the potential link between aggregation and nutrient cation $(\mathrm{Ca}$, $\mathrm{Mg}$ ) availability. For this purpose, two forest soils of the Lorraine plateau (France), both classified as Luvisols ruptic (WRB) but displaying different levels of exchangeable nutrient cation (Bedel et al. 2016), were studied, looking more particularly at soil aggregate size distribution and their properties (chemical, physical, mineralogical).

\section{Material and methods}

\subsection{Study sites}

This project was conducted at two experimental sites (5 ha each) set up in deciduous forests of the Lorraine plateau (North-Eastern France). The first site named CA is located in the "Grand Pays" state forest at Clermont-en-Argonne ( $\left.49^{\circ} 06^{\prime} 23^{\prime \prime} \mathrm{N}, 5^{\circ} 04^{\prime} 18^{\prime \prime} \mathrm{E}\right)$ and the stand (mixed beech, oak, birch, and maple; 70 to 80 years old; dominant height $30.6 \pm 5.9 \mathrm{~m}$ ) is developed on a "gaize" bedrock (Gaize d'Argonne, Cenomanian). This siliceous sedimentary rock is usually permeable and poor in weatherable minerals, but can locally lead to a rather clayey saprolite. It is covered by a silty quaternary continental deposit (decarbonated), about $50 \mathrm{~cm}$ thick. The second site named AZ is located in the "HautsBois" estate forest at Azerailles (48 $29^{\circ} 19^{\prime \prime} \mathrm{N}, 6^{\circ} 41^{\prime} 43^{\prime \prime}$ E) and the stand (mixed beech and oak; 70 to 80 years old; dominant height $33.3 \pm 6.7 \mathrm{~m}$ ) is developed on a clayey saprolite of Keuper marls which are covered by a quaternary alluvial silt deposit, also about $50 \mathrm{~cm}$ thick.

The CA and AZ sites have respectively an elevation of 270 and $300 \mathrm{~m}$ a.s.l., mean annual temperatures of $9.5^{\circ} \mathrm{C}$ and $9{ }^{\circ} \mathrm{C}$ and mean annual rainfall (average over 30 years) close to 900 and $1000 \mathrm{~mm}$ (Kessler and Chambraud 1986). These sites were designed to study the impact of soil compaction on ecosystem functioning (Bottinelli et al. 2014; Capowiez et al. 2015; Goutal et al. 2016). However, all the observations, measurements and sampling for this study were carried out before the setting up of these experiments or on the control treatment of the experiments. Hence, the compacted treatments were not used in this study.

\subsection{Soil description, sampling, preparation, and field measurements}

Thirteen evenly distributed pits at $\mathrm{CA}$ and 17 at $\mathrm{AZ}$ were used for soil description and sampling. Soils of the two sites are Luvisols (ruptic) according to the World Reference Base for Soil Resources (WRB 2014) and Neoluvisols bilithique according to Référentiel Pédologique (Baize and Girard 2008), with an analogous physical organization dominated by silt in the upper $50 \mathrm{~cm}$ and a strong increase in their clay content in the deeper horizons. The strong clay enrichment at about 
$50 \mathrm{~cm}$ depth causes a temporary water table to invade the silt horizon during wet periods without leading to a typical hydromorphic soil. The sequence of horizons according to Référentiel Pédologique (Baize and Girard 2008) is as follows: A (0-10 cm), E (10-35 cm), BT $(\mathrm{g})(40-60 \mathrm{~cm}), \mathrm{S}$ $(60-70), \mathrm{C}(>70 \mathrm{~cm})$ at $\mathrm{AZ}$ and $\mathrm{A}(0-13 \mathrm{~cm}), \mathrm{E}(\mathrm{g})(10-$ $40 \mathrm{~cm}), \mathrm{BTg}(40-75 \mathrm{~cm}), \mathrm{C}(>75 \mathrm{~cm})$ at CA.

For the $<2-\mathrm{mm}$ soil class (fine earth) characterization, soil samples were collected in each pit at systematic depths down to $75 \mathrm{~cm}(0-10 ; 10-20 ; 20-30 ; 30-45 ; 45-60 ; 60-75 \mathrm{~cm})$ and in three pits per site below $75 \mathrm{~cm}$ depth $(75-100,>100 \mathrm{~cm}$ at AZ; 75-90, 90-110, >110 cm at CA). Soil samples were airdried at the laboratory and sieved to separate coarse material from the $<2 \mathrm{~mm}$ class (fine earth); soil moisture was measured after oven-drying at $105{ }^{\circ} \mathrm{C}$ of all samples. The total number of samples processed was 104 at CA and 136 at AZ.

\subsection{Characterization of the $<2 \mathrm{~mm}$ class (fine earth)}

\subsubsection{Properties of the $<2 \mathrm{~mm}$ class}

Particle size distribution was measured after oxidation of organic matter by $\mathrm{H} 2 \mathrm{O} 2$ (Kunze and Dixon 1986). Soil pH was measured in both $1 \mathrm{M} \mathrm{KCl}$ and in distilled water, with a soil to solution weight ratio of 1:2.5 (Mettler TSDL25 pH meter). Cation-exchange capacity (CEC) and exchangeable cation contents were measured by the colbaltihexamine $(50 \mathrm{mmol}$ $+\mathrm{L}^{-1}$ ) extraction method with a soil to solution weight ratio of 1:20 (Ciesielski et al. 1997).

Total soil organic carbon (Corg) and nitrogen (Norg) contents were analyzed with a combustion system (Thermo Quest NCS 2500); total content of $\mathrm{Al}, \mathrm{Fe}, \mathrm{Mg}, \mathrm{Ca}, \mathrm{K}, \mathrm{Na}$, and $\mathrm{Mn}$ in the $<2$ mm class (fine earth) were determined after HF digestion and ICP-AES measurements at the Inra-Soil Analysis Laboratory (LAS- Arras). Fe and Al oxides were quantified according to the method described in Mehra and Jackson (1960) using dithionite-citrate buffered with sodium bicarbonate with a soil to solution weight ratio of 1:75 (1960).

\subsubsection{Mineralogy of the clay fraction}

Clay mineralogy of the $<2 \mathrm{~mm}$ class (fine earth) was characterized for the soil samples collected at the central pit at each site ( 8 horizons per profile).

The clay fraction $(<2 \mu \mathrm{m})$ was extracted from the $<2-\mathrm{mm}$ class (fine earth) according to Robert and Tessier (1974). The soil organic matter was digested using the daily addition of dilute hydrogen peroxide $(20 \mathrm{v})$ to fresh samples put on heating plates maintained at about $40^{\circ} \mathrm{C}$ until total elimination of organic carbon. Samples were then introduced in bottles filled with distilled water to separate particle classes according to Stokes law of sedimentation for dilute systems. The clay and the fine silt $(2-50 \mu \mathrm{m})$ fractions were separated by siphoning until total disappearance (10 to 15 siphoning operations are usually necessary); then the coarser fractions (coarse silts, fine, and coarse sands) were quantified by sieving under distilled water.

The total analysis was performed on particle size fractions by the CNRS-CRPG rock and mineral analysis laboratory, using LiBO2 alkaline fusion and dissolution in $1 \mathrm{~N} \mathrm{HNO}$. Concentrations were measured by ICP-OES for major element and by ICP-MS for trace elements (Carignan et al. 2001).

Clays were then saturated with barium $(\mathrm{Ba})$, which is not abundant in soil, to measure the cation-exchange-capacity directly from the total analysis.

The fine clay fraction $(<0.1 \mu \mathrm{m})$ was separated from the total clay fraction by centrifugation according to (Hathaway 1958):

$t=\frac{9}{2} \times \frac{\eta}{\omega^{2} \phi^{2}(\rho-\rho 0)} \times \ln \frac{\mathrm{Rmax}}{\mathrm{Rmin}}$

where $t$ (in s) is the centrifugation time; $\eta$ is the water viscosity $\left(\mathrm{g} / \mathrm{cm} \mathrm{s} ; \omega\right.$ is the angular velocity $\left(\operatorname{rad~sec}^{-1}\right) ; \phi$ is the maximum radius of particles $(m) ; \rho$ is the specific gravity of water $\left(\mathrm{g} \mathrm{cm}^{-3}\right) ; \rho 0$ is the specific gravity of particles $\left(\mathrm{g} \mathrm{cm}^{-3}\right)$; Rmax the minimal radius of the rotor (upper part of the sample) $(m)$ and Rmin the maximum radius of the rotor (lower part of the sample) $(m)$. Using the KR4I Jouan apparatus, it was necessary to centrifuge for $1 \mathrm{~h} 40$ at 3000 rot $\mathrm{min}^{-1}$, with $R \max =28 \mathrm{~cm}$ and $\mathrm{Rmin}=16 \mathrm{~cm}$. The $0-2-\mu \mathrm{m}$ clay fraction was dispersed using ultrasonic dispersion before centrifuging; the supernatant was collecting by siphoning. The dispersion/ centrifugation/siphoning operation was repeated eight times to collect the largest part of the fine clay material.

After various saturations [e.g., barium (Ba), potassium (K), and ethylene glycol (EG)] under controlled air humidity and specific pre-treatments to specifically destabilize and quantify Fe cement (Mehra and Jackson 1960) or Al cement (Tamura 1958), oriented clay samples were deposited on glass slides and dried overnight at room temperature before diffraction measurements using a Siemens XRD Diffractometer D5000 (2 theta: $3-63,0.035,323.9 \mathrm{~s}, 25^{\circ} \mathrm{C}$ ). Tamura method was used to differentiate between primary chlorite and chlorite-like HIV (hydroxy-interlayered-vermiculite): this extraction is specific for interlayered-Al (abundant in acidic soils). Mehra Jackson method (dithionite-citrate-bicarbonate, DCB) was used more specifically to destabilize iron oxi-hydroxides. This strong redox reaction removes $\mathrm{Fe}$, but also $\mathrm{Al}$ associated with Fe-Al mixed oxides; it is also known to cause some destabilization of primary structures (Jeanroy 1983).

The Hoffmann and Klemen test were used to determine the location of the negative charges within the dioctahedral smectite 2:1 layer (Greene-Kelly 1953; Hoffmann and Klemen 1950). The clay fraction $(<2 \mu \mathrm{m})$ was Li-saturated using 1 $\mathrm{N}-\mathrm{LiCl}$ (solid solution ratio 1:10), then rinsed several times 
until $\mathrm{Cl}$ - was totally eliminated (AgNO3 test). An oriented preparation of the Li-clay fraction was heated at $300^{\circ} \mathrm{C}$ for $5 \mathrm{~h}$, then saturated with ethylene glycol before XRD analysis.

\subsection{Characterization of aggregation}

At both sites, fresh samples were collected in one additional pit for aggregate characterization. Four soil layers characterizing four contrasted conditions were sampled: the surface organic layer $(0-10 \mathrm{~cm})$, the silty and low $\mathrm{C}$ content layer $(10-20 \mathrm{~cm})$, a medium depth layer $(30-45 \mathrm{~cm})$ intermediate between the loamy and the clayed units and a deep clayey layer (from 50 to $120 \mathrm{~cm}$ ). Four replicates (one per pit face) were collected at each depth and pooled in the field. The deep layer was sampled but only bulk soil was studied at a 100120 -cm depth because it was impossible to separate aggregates in such a clayey material. Samples were stored at $4{ }^{\circ} \mathrm{C}$ until aggregate separation.

\subsubsection{Soil aggregate size fractionation}

The soil aggregate separation method used in this study is based on the methods used to study carbon turnover rates and the different protection of SOM according to aggregate stability (Billings 2006; Jiménez et al. 2011; Moni et al. 2010, 2012). After some preliminary tests, it appeared that the method used by Andreux et al. (1980) or Balesdent et al. (1998) to separate aggregates in agriculture soils would lead to complete soil disaggregation in the loamy layers due to the acidic $\mathrm{pH}$ of the studied soils and the low stability of soil aggregates. We then adapted the method used by Balesdent et al. (1998) or Clark et al. (2010), eliminating the mechanical shaking phase: $200 \mathrm{~g}$ of dry soil were slowly water saturated by imbibition with ultrapure distilled water. Using 2000-, 200- and 50- $\mathrm{mm}$ mesh sieves allowed to separate the coarse aggregates [2000$200 \mu \mathrm{m}]$, the intermediate aggregates $[200-50 \mu \mathrm{m}]$ and the fine aggregates $[<50 \mu \mathrm{m}]$ through gentle sieving. The first two classes contain only aggregates while the $[<$ $50 \mu \mathrm{m}]$ class contains both micro-aggregates and individual particles. Two origins were supposed for these particles: either real free particles in the soil or particles produced by disaggregation of fragile aggregates during the sieving operation.

After separation, all aggregate classes were first oven dried at $65^{\circ} \mathrm{C}$ (in order to eliminate the water excess) then at $35^{\circ} \mathrm{C}$, avoiding a total drying of the solid phase. The walls of the beakers were daily cleaned using a glass stick with a Teflon tip, to avoid fine particles loss.

The abundance of aggregates in the different classes (2000-200 $\mu \mathrm{m}, 200-50 \mu \mathrm{m} ;<50 \mu \mathrm{m}$ ) was computed for each horizon and site.

\subsubsection{Granulometry, clay mineralogy, and chemical analysis of aggregates}

For each horizon and site, a first aliquot of the aggregate classes was dedicated to particle size distribution measurements and clay mineralogy. The methods used are similar to those used for the fine earth. A second aliquot of each aggregate class was fully dissolved using concentrated acid for total analysis $(1 \mathrm{ml}$ of $\mathrm{HF}$ and $6 \mathrm{ml}$ of $\mathrm{HNO} 3$ added to 1-g dry aggregates at $130{ }^{\circ} \mathrm{C}$; the solution was then evaporated and the residue was dissolved with $7 \mathrm{M} \mathrm{HCl}$ to measure the major element concentrations using ICP-OES (Agilent Technologies -700 Series). A third aliquot was used for the extraction of exchangeable cations using $1 \mathrm{M} \mathrm{NH4OAc}$ at $\mathrm{pH} 7$. This reagent was preferred to colbaltihexamine in this part of the study to be able to later carry out $\mathrm{Mg}$ and $\mathrm{Ca}$ isotopic ratio analysis: $40 \mathrm{ml}$ of solution were added to $4 \mathrm{~g}$ of dry aggregates (solid solution ratio 1:10). Two successive extractions were carried out $24 \mathrm{~h}+1 \mathrm{~h}$. Major element concentrations were measured by ICP-OES (Agilent Technologies -700 Series).

\subsection{Statistical analyses}

Elementary statistics were used on the general soil properties at the two sites to characterize the mean values and standard deviations from replicate measurements. Variance analysis (using all replicated pits) followed by Tukey's tests at the 95\% level were performed at each site on the fine earth dataset down to $75-\mathrm{cm}$ depth in order to identify a depth effect. Student's $t$ tests (using all replicated pits) were also performed for each soil layer down to $75-\mathrm{cm}$ depth to identify a site effect. The statistical dependence between variables was assessed using the Pearson's correlation coefficient, as linear relationships were observed. Lastly, a principal component analysis (PCA, XLSTAT 2013.3.04) was performed to identify the main variables discriminating sites. Several PCA based on different combinations of available variables collected on the aggregate classes were tested.

\subsection{Validity of the approach}

In order to evaluate the coherence between the $<2 \mathrm{~mm}$ class (fine earth) analysis and the aggregate class analysis, we recalculated total $<2 \mathrm{~mm}$ class (fine earth) concentrations from the concentrations measured in the different aggregate size classes. First, we calculated the weighted mean cation saturation for a layer from the proportion of each aggregate class (same elements were measured in both cases, except $\mathrm{H}$ which represents about $10 \%$ of the saturating cations). Then, we calculated the CEC of the soil layer using the base saturation rate, assuming that the methodology used for the extraction of exchangeable cations (e.g., cobaltihexamine for 
total soil and $\mathrm{NH} 4+-$-acetate at $\mathrm{pH} 7$ for fractions) did not change this rate.

\section{Results}

\subsection{Characteristics of the fine earth}

\subsubsection{Texture}

Both soils were loamy textured in the upper layers and clayey textured below 50-cm depth (Table 1). Clay eluviation occurred in the silt cover, leading to a significant increase in clay content below $30-\mathrm{cm}$ and $45-\mathrm{cm}$ depth respectively at CA and AZ. Nevertheless, significant differences were observed between the soils of the two sites (Table 1), with lower clay content at $\mathrm{CA}$ than at $\mathrm{AZ}$ in the soil layers down to $75-\mathrm{cm}$ depth.

\subsubsection{Clay mineralogy}

At the CA site, the clays in the deep layers consisted of an admixture of kaolinite, illite, and smectite (Supplementary File 1, Supplementary File 2). The Hoffmann-Klemen test indicated a tetrahedral charge deficit for the smectite, characteristic of the Beidellite group. In the upper soil layers, kaolinite, illite, and a 1.4-nm phase dominated; the beidellite content strongly decreased in both pure and interstratified phases (changes occurred at about $45-\mathrm{cm}$ depth).

At the AZ site, the mineralogy of the clay fraction of the deeper soil layers was rather simple, with a dominant illite mineral associated with traces of kaolinite (Supplementary File 1, Supplementary File 2). In the upper soil layers, three phases occurred: kaolinite, illite, and a 1.4-nm phase composed of chlorite and of vermiculite more or less interstratified (Supplementary File 1).

\subsubsection{Soil chemistry}

Soil chemistry at both sites is summarized in Table 1. The $\mathrm{pH}$ water of the soil layers down to $30-\mathrm{cm}$ depth was significantly higher at $\mathrm{AZ}$ compared to $\mathrm{CA}$ and a significant increase was observed at both sites from the surface to depth. Organic carbon and nitrogen contents were significantly higher at AZ than at CA. The total soil cationic exchange capacity (CEC) was similar between sites except in the 0 - to $20 \mathrm{~cm}$ layers and significantly increased with depth at both sites (from 3.5 to $4.5 \mathrm{cmol}+\mathrm{kg}^{-1}$ in the surface layers to 12 to $18 \mathrm{cmol}+\mathrm{kg}^{-1}$ in depth). The $\mathrm{Ca}$ and $\mathrm{Mg}$ contents were significantly higher in the $0-10-\mathrm{cm}$ and $0-$ 20-cm layers at AZ than at CA, respectively. The Al content in the 0-10-cm layer was significantly lower at AZ compared to $\mathrm{CA}$ and base cation saturation (BS) was significantly higher in the $0-10-\mathrm{cm}$ layer at $\mathrm{AZ}$ than at $\mathrm{CA}$.

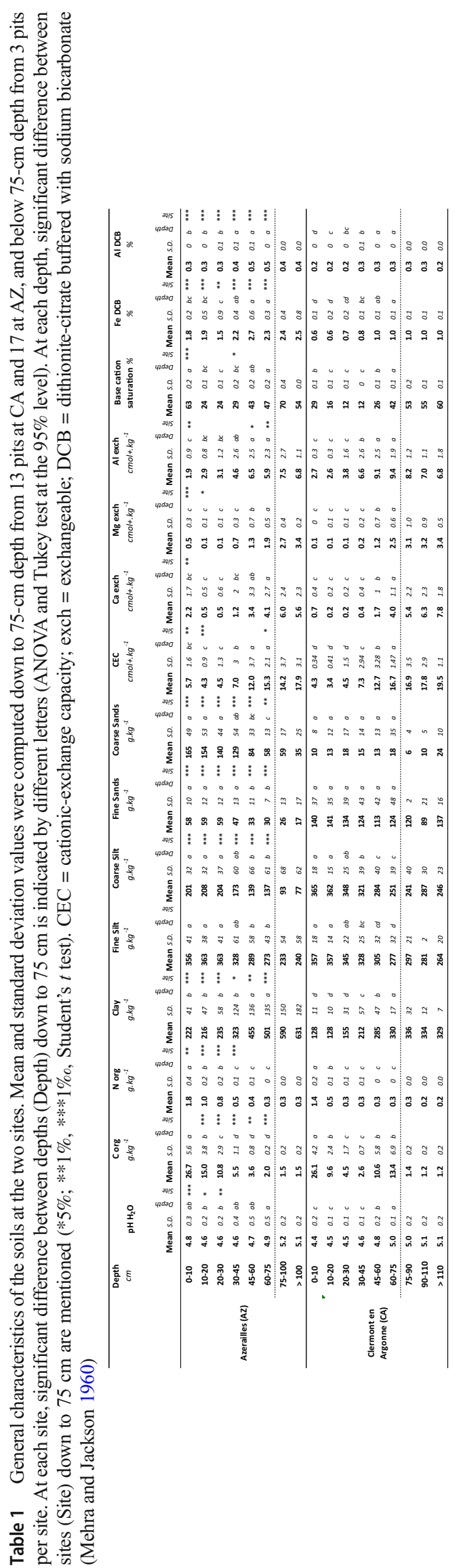




\subsection{Chemical composition of particle size fractions}

Total analysis of the different particle size fractions (clays, fine silts, coarse silts, fine sands, and coarse sands) are presented in Table 2. When comparing the two sites, significant content differences were observed for $\mathrm{SiO} 2$ in fine sands, $\mathrm{Al} 2 \mathrm{O} 3$ in fine silts and fine sands, $\mathrm{Fe} 2 \mathrm{O} 3$ in sands, and $\mathrm{MnO}$ in coarse sands (Table 2). The geological origin of the material easily explained these differences between sites, with the occurrence of Fe rich glauconite in the sand fraction at CA (Albian/ Cenomanian substratum). Within a site and for a given soil particle size class, the total chemical composition of soil particles was not significantly different between aggregate size classes and soil horizons (data not shown).

\subsection{Abundance of aggregate size classes}

In the AZ soil, the abundance of coarse aggregates [200$2000 \mu \mathrm{m}]$ decreased with depth, from $45 \%$ in the $[0-10 \mathrm{~cm}]$ layer to $24 \%$ in the [30-45 cm] layer (Fig. 1a). The less represented class was the intermediate class, which represented about $20 \%$ of the $<2 \mathrm{~mm}$ class (fine earth) in the surface layers $[0-20 \mathrm{~cm}]$ and slightly increased to reach $28 \%$ in the $[30-45 \mathrm{~cm}]$ layer. The fine aggregates represented $31 \%$ in the $[0-10 \mathrm{~cm}]$ layer, reaching $50 \%$ at $[20-45 \mathrm{~cm}]$ depth. In the surface layer $[0-10 \mathrm{~cm}]$, coarse aggregates dominated while the finest ones $[<50 \mu \mathrm{m}]$ dominated in the deeper layers.

At CA, coarse aggregates [200-2000 $\mu \mathrm{m}$ ] always represented less than $25 \%$ of the $<2 \mathrm{~mm}$ class (fine earth), reaching a minimum of $11 \%$ in the $[10-20 \mathrm{~cm}]$ layer (Fig. 1b). The intermediate class $[50-200 \mu \mathrm{m}]$ represented more than $50 \%$ of the $<2 \mathrm{~mm}$ class (fine earth) in the $[0-20 \mathrm{~cm}]$ layer. This intermediate class decreased with soil depth but still represented more than $40 \%$ in the [30-45 cm] layer. In this layer, the finest aggregate class $[<50 \mu \mathrm{m}]$ increased to reach $40.5 \%$, so their abundance is equivalent to that of the intermediate class.

\subsection{Major element contents of the aggregate size classes}

At $\mathrm{CA}$, the highest concentrations of $\mathrm{C}$ and $\mathrm{N}$ were found in the finest class $[<50 \mu \mathrm{m}]$ and the lower ones in the intermediate class [50-200 $\mu \mathrm{m}$ ] (Supplementary File 3). The C:N ratio was the highest in the coarse aggregate class [200$2000 \mu \mathrm{m}]$. At AZ, the same tendency was observed below $10 \mathrm{~cm}$ depth, but in the soil surface layer, the concentrations of $\mathrm{C}$ decreased with the size of aggregates.

Total and exchangeable $\mathrm{Ca}$ and $\mathrm{Mg}$ concentrations were always lower at CA than at $\mathrm{AZ}$ (except for total $\mathrm{Mg}$ at $[100$ $120 \mathrm{~cm}$ ] depth) (Supplementary File 3). Changes in total $\mathrm{Ca}$ concentration according to the aggregate size did not show any clear trend at $\mathrm{CA}$, whereas in $\mathrm{AZ}$ intermediate aggregate size class tended to be the most concentrated for each depth.

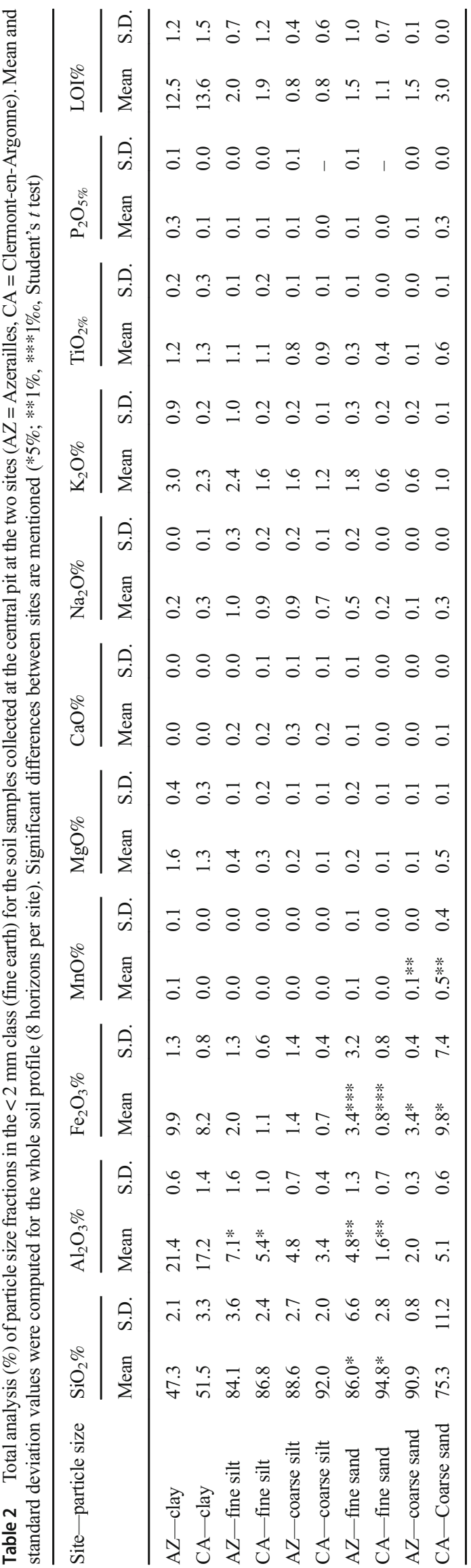


Exchangeable $\mathrm{Ca}$ distribution was different from total $\mathrm{Ca}$ in aggregate classes, but exchangeable $\mathrm{Ca}$ contents had similar relative trends at both sites: the highest concentrations were measured in the finest aggregates and the lowest one in the intermediate class (Fig. 2), whatever the horizon. At CA, the lowest concentrations of total $\mathrm{Mg}$ were found in the intermediate aggregate size class while at AZ no clear trend was observed between total $\mathrm{Mg}$ and aggregate size class. At both sites, the highest total $\mathrm{Mg}$ concentrations were observed in the finest aggregate size class of the topsoil $(0-20 \mathrm{~cm})$. At both sites, the distribution of exchangeable $\mathrm{Mg}$ was the same as exchangeable $\mathrm{Ca}$, with the highest concentrations observed in the finest aggregates and the lowest in the intermediate ones (Fig. 2).

At both sites, the lowest exchangeable to total ratios for both $\mathrm{Ca}$ and $\mathrm{Mg}$ were found in the intermediate aggregate class $[50-200 \mu \mathrm{m}]$ (Supplementary File 3). The highest Caexch:CaTot and Mgexch:MgTot ratios were not observed in the same aggregate class at $\mathrm{CA}$ and $\mathrm{AZ}$ on the surface horizon: at $\mathrm{CA}$, these ratios were the highest for the finest aggregate class $[<50 \mu \mathrm{m}]$, while at AZ it was in the coarser class $[200-2000 \mu \mathrm{m}]$.

\subsection{Particle size distribution of the aggregate size classes}

The results presented in Supplementary File 4 indicated that the distribution of individual particle size in the three aggregate classes was more specific of the aggregate class considered, than of the site. Clays represent 20 to $40 \%$ of the finest aggregate size class $[<50 \mu \mathrm{m}]$ while the lowest $(<10 \%)$ was found in the intermediate class $[50-200 \mu \mathrm{m}]$. Fine silts dominated the fine class $[<50 \mu \mathrm{m}]$ of both soils; the lowest abundances were observed in the intermediate aggregate size class $[50-200 \mu \mathrm{m}]$ at $\mathrm{CA}$ but not at $\mathrm{AZ}$ where their abundances increased with the aggregate size. Coarse silts represent 40 to $50 \%$ of the intermediate aggregate size class at $\mathrm{CA}$ and 25 to $35 \%$ at $\mathrm{AZ}$; the lowest abundances were

a

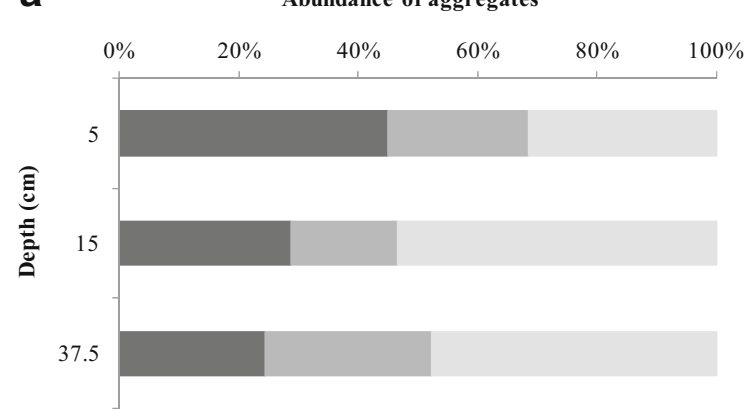

found in the finest aggregate size class in $\mathrm{CA}$ and in the largest class in AZ. Fine sands were more abundant in the intermediate aggregate size class $[50-200 \mu \mathrm{m}]$ than in the other classes. Lastly, coarse sands can only be found in the larger size class, but their proportion in the coarse aggregates was strongly related to the site (less than $2 \%$ in the surface horizons of CA vs 43 to $55 \%$ at AZ).

\subsection{Clay mineralogy of the aggregate size classes}

At CA, very weak differences appeared after normalization of the diagrams of the clay fraction by the illite intensity peak (Supplementary File 5). This normalization was carried out after the EG treatment and/or after [Tamura $+\mathrm{K}+550^{\circ} \mathrm{C}$ ] treatments, for the $[<50 \mu \mathrm{m}]$ and $[50-200 \mu \mathrm{m}]$ aggregate classes. Some complex interstratified mineral belonging to the beidellite-illite type would vary according to aggregate class. The fine clay fraction $(<0.1 \mu \mathrm{m}) \mathrm{XR}$ traces showed that swelling clays present in the fine and coarse aggregates were not detected in the intermediate class [50-200 $\mu \mathrm{m}$ ] (data not shown).

At AZ, some small differences appeared after normalization of the diagrams on the treatment [Tamura $+\mathrm{K}+$ heating at $\left.550{ }^{\circ} \mathrm{C}\right]$ of the clays from the $[<50 \mu \mathrm{m}]$ class, which would refer to chlorite stability (Supplementary File 5). The fine clay fraction $(<0.1)$ revealed the occurrence of some swelling particles in the fine and coarse aggregate classes, but not in the intermediate size class [50-200 $\mu \mathrm{m}$ ] (data not shown).

\subsection{Multivariate analysis}

A multivariate analysis which summarized the physical and chemical properties of the two soils is presented in Fig. 3. The $\mathrm{F} 1$ and F2 axis explained $87 \%$ of the total variance and discriminated satisfactorily the two soils and their respective horizons. CA soil upper horizons were related to the coarse silt fraction characteristic while the coarse sand fraction discriminated the $\mathrm{AZ}$ soil upper layer. Organic $\mathrm{C}$ opposed to clay on

b

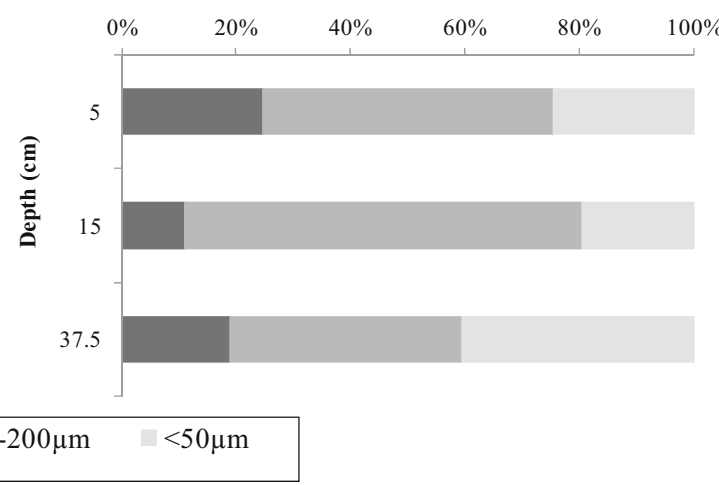

Fig. 1 Abundance of aggregate classes (200-2000 $\mu \mathrm{m} ; 50-200 \mu \mathrm{m} ;<$ $50 \mu \mathrm{m})$ at the three sampled depths $(0-10 \mathrm{~cm}, 10-20 \mathrm{~cm}$, and $30-45 \mathrm{~cm})$ at Azerailles (A) and Clermont-en-Argonne (B). Samples were collected in one pit per site; four replicates (one per pit face) were collected at each depth and pooled in the field 

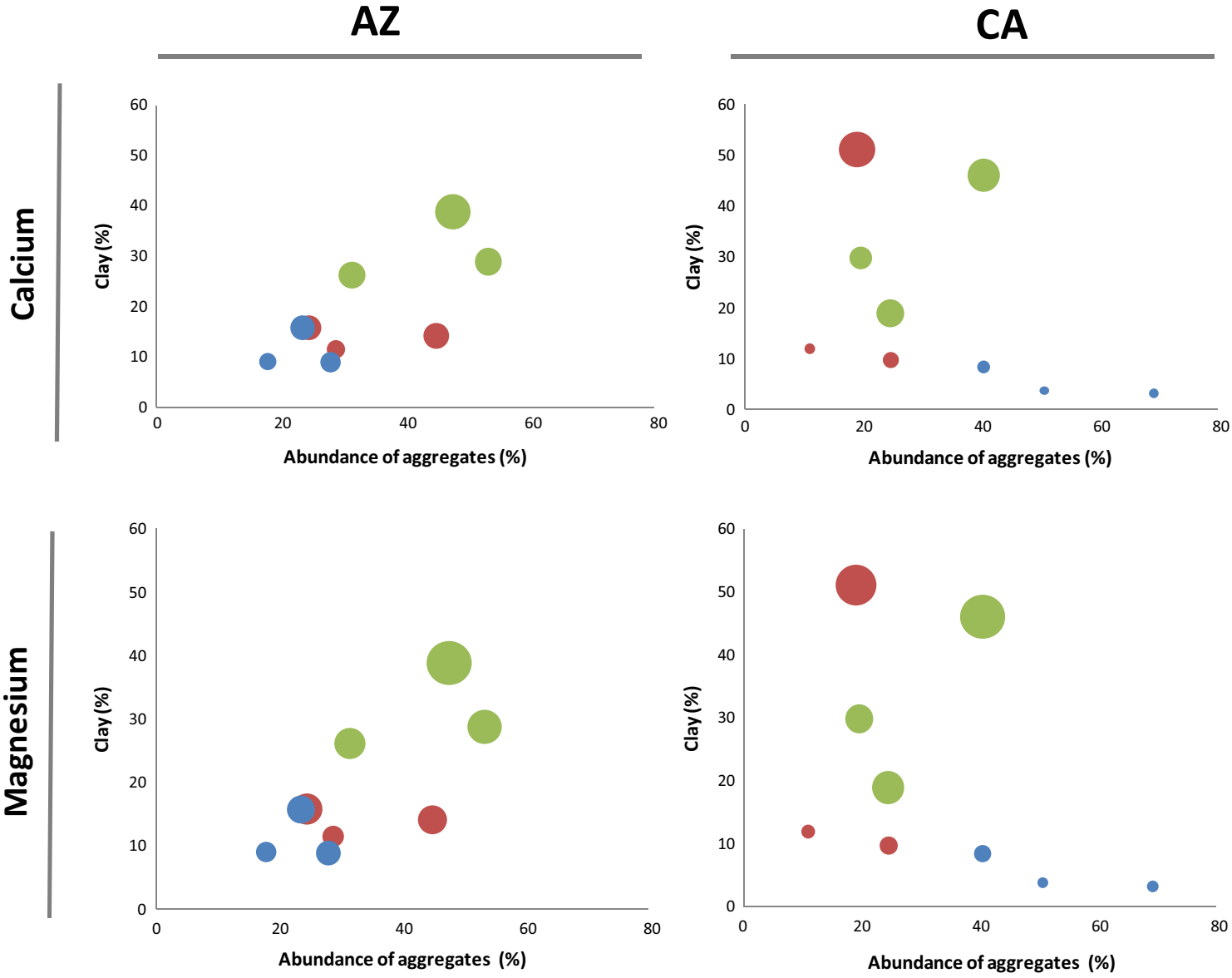

\section{$\bullet 200-2000 \mathrm{um}$
Symbol size proportional to Calcium or Magnesium content $\left(\mu \mathrm{g} \cdot \mathrm{g}^{-1}\right)$}

Fig. 2 Relationships between the clay content of an aggregate class, the abundance of the class and its concentration in exchangeable calcium or magnesium at the two sites. $\mathrm{AZ}=$ Azerailles; $\mathrm{CA}=$ Clermont-en-

the $\mathrm{F} 2$ axis contributed to discriminate the horizon depths. The CA soil was related to the intermediate aggregates while the $\mathrm{AZ}$ soil was related to the coarse and fine aggregates.

\subsection{Relationship between measured and estimated CEC}

The results presented in Supplementary File 6 showed satisfactory agreement between the CEC measured on the fine earth and the CEC estimated from the aggregate class. The difference in sampling and method used could explain the limited discrepancy and tended to validate our approach. Nevertheless, the two outliers, corresponding to the AZ subsurface samples $([10-20 \mathrm{~cm}]$ and $[30-45 \mathrm{~cm}]$ layer), suggested that in some cases, soil analysis of the total $<2 \mathrm{~mm}$ class (fine earth) or separate aggregate classes does not lead to
Argonne. Samples were collected in one pit per site; four replicates (one per pit face) were collected at each depth and pooled in the field. Symbol size is proportional to calcium or magnesium content

the same result. We may hypothesize that the geometry of the efficient ion-exchanger (i.e., accessibility of surfaces) changed between aggregates and fine earth.

\section{Discussion}

In the framework of this study, we developed a soil aggregate separation method adapted to forest soils and acidic soils in particular. Due to the lengthy aspect of this separation method, we were unable to apply it to multiple replicates of soil samples for each investigated depth $(0-10,10-20$, and $30-45 \mathrm{~cm})$. However, to our knowledge, few studies have investigated and measured soil aggregate classes in forest soils making this dataset, which combines different approaches, rather unique and original. The study of the fine earth shows that the $\mathrm{Ca}$ 
Fig. 3 Results of the principal component analysis on aggregate characteristics summarizing the discrimination between the two soils. The $x$ and the $y$ axis represent respectively the first and second factor of the principal component analysis. The percentage of explained variance for each principal component is indicated in brackets. The contributing variables are colored in red. $\mathrm{AZ}=$ Azerailles; $\mathrm{CA}=$ Clermont-en-Argonne; $\mathrm{CEC}=$ cationic-exchange capacity; DCB $=$ dithionite-citrate buffered with sodium bicarbonate (Mehra and Jackson 1960); Exch = exchangeable. Abundance of aggregate classes (200-2000 $\mu \mathrm{m}$; 50-200 $\mu \mathrm{m} ;<50 \mu \mathrm{m}$ ) are supplementary variables

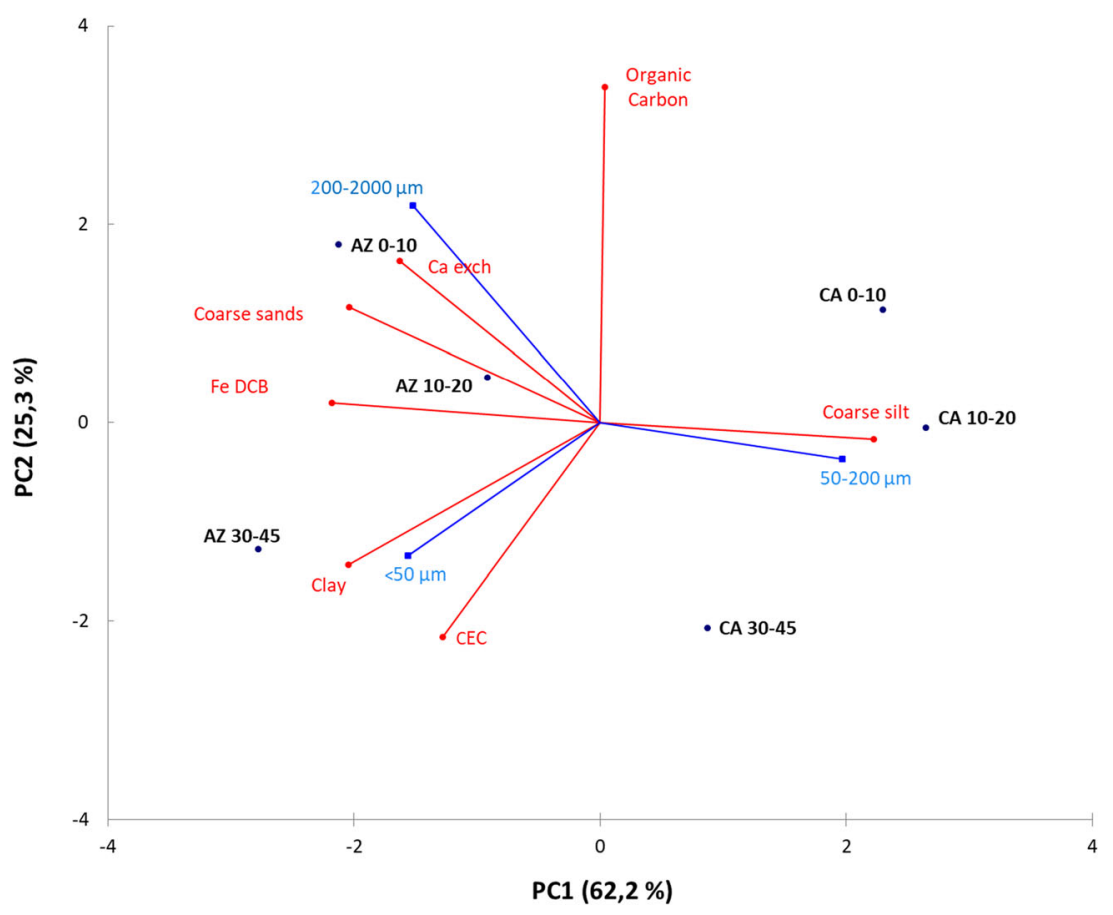

and $\mathrm{Mg}$ availability in the upper soil layers assessed through ion exchange were significantly different between sites. Although no statistical tests could be performed to support the observed differences in soil aggregation between both studied sites, these differences were large and enable to discuss the potential relations between soil aggregation and nutrient cation availability to tree uptake at these two sites.

\subsection{Differences in the soil aggregation status between the two soils}

The gentle method used in this study for separating aggregates allowed us to observe differences in terms of aggregation, between the two soils. The intermediate class [50-200 $\mu \mathrm{m}]$ dominated at CA while the coarse and fine aggregate classes were dominant at AZ. Several parameters detailed below may contribute to explaining these differences.

Firstly, the low clay content at CA may limit the cement effect of clays (Horn 1990) and the occurrence of a low, but significant amount of swelling clays in coarse and fine aggregate classes at CA may decrease aggregate stability. Singer (1994) and Stern et al. (1991) observed similar patterns: a low rate of smectite associated with kaolinite and illite decreased the aggregate stability. The relatively low content of Fe and $\mathrm{Al}$ oxides and the lower soil $\mathrm{C}$ content and organic matter quality $(\mathrm{C}: \mathrm{N})$ at $\mathrm{CA}$ compared with $\mathrm{AZ}$ could also limit the efficiency of cementation.

Secondly, the $\mathrm{pH}$ and base cation saturation were slightly lower in the upper soil layer at CA compared to AZ. This small difference was nevertheless important for soil biogeochemistry: soil $\mathrm{pH}$ at $\mathrm{CA}$ was below the first $\mathrm{pK}$ of the $\mathrm{Al}$ hydrolysis reactions. The stability of the Al-monomeric chemical form strongly increases below pH 4.5 (Zelazny and Jardine 1989) impacting both geochemical (CEC saturation) (Julien et al. 2007) and biological processes (earthworms, microbial activity) (Hobbie et al. 2006). Both $\mathrm{Al}$ and Ca cations are flocculating agents; however, depending on clay mineralogy, their different hydrolysis constants could lead to changes in the flocculation process (Zelazny and Jardine 1989; Haynes and Naidu 1998). The greater abundance of exchangeable $\mathrm{Al}$ at $\mathrm{CA}$ (Al:Ca ratio was twofold higher at $\mathrm{CA}$ ) could thus induce differences in terms of aggregation.

Lastly, the soil acidity at CA led to the disappearance of anecic earthworms (Bottinelli et al. 2014) known to act as engineers of the soil structure. Roots and fungi were then the only biological agents contributing to aggregation, essentially during the growing season. Conversely, at $\mathrm{AZ}$, the higher soil $\mathrm{pH}$ and exchangeable $\mathrm{Ca}$ and $\mathrm{Mg}$ pools allowed the occurrence of a higher biological activity (e.g., anecic earthworms were observed Bottinelli et al. 2014 and Capowiez et al. 2015).

\subsection{Assessing the dynamic of soil aggregation}

Previous studies on soil aggregate dynamics suggest that the fine and intermediate aggregate classes are formed from the collapsing of macro-aggregates (Piccolo et al. 1997; Bronick and Lal 2005; Reichert et al. 2009). At CA, the C:N ratios of fine aggregates do not suggest the presence of organic cement resulting from biological activity (von Lützow et al. 2007). Moreover, the intermediate aggregate class had low Corg content, with $\mathrm{C}: \mathrm{N}$ values between those of coarse and fine classes, 
and a low clay content, without any very fine clays. These findings agree with the hypothesis that intermediate aggregates at $\mathrm{CA}$ originated from the collapsing of macro-aggregates. The soil resistance to penetration was measured at both sites (data not shown). The soil mechanical properties estimated from this method are in agreement with a collapsing structure at CA (data not shown).

$\mathrm{n}$ the $\mathrm{AZ}$ soil, our results concurred with the concept of Christensen (1992): the fine aggregates are expected to be enriched in evolved and protected organic matter (Balesdent et al. 2000; Oades and Waters 1991; Schmidt et al. 2011; Six et al. 2004) and in reactive clay particles. The fine aggregates at AZ had the highest clay content, and the lowest $\mathrm{C}: \mathrm{N}$ value, without nevertheless having the highest Corg content. The coarse aggregates are expected to be enriched in organic matter belonging to the active pool because the fresh detritus are rapidly decomposed by microbes (Oades 1984), with none or few reactive minerals (sand or silt material with low surface area and low bonding affinities with organic material) (von Lützow et al. 2007). This is consistent with our results: the coarse aggregates at AZ had the highest Corg content and lower CEC than fine aggregates.

Though the dynamics of aggregation-desegregation were difficult to assess with our dataset, the physical and chemical properties of the different aggregate classes suggest that soil aggregation was more stable at AZ than at CA. Interestingly, clay content and mineralogy appeared to be key elements for aggregate formation and stability at our study sites. However, the present data are insufficient to conclude on this hypothesis and further investigations would be necessary.

\subsection{Consequences for nutrient cation retention}

Clay content and mineralogy, as well as organic matter content and quality, are key parameters that contribute to the CEC and consequently to the nutrient cation retention in soils. At both sites, there was no evidence of a relation between aggregate size and clay mineralogy: contrarily to what was observed by Fernández-Ugalde et al. (2013), our results suggested that neither the clay type nor specific clay properties were associated with aggregate size classes. However, clay content clearly appeared as a driver for nutrient cation retention in the different aggregate classes of the loamy upper soil horizons: correlation coefficient values between clay and nutrient cations were always significant at $\mathrm{CA}$ and $\mathrm{AZ}$ and greater than 0.85 (data not shown). Paradoxically, there was only a limited effect of Corg on the retention of nutrient cations (correlation coefficient values between Corg and nutrient cations for $\mathrm{AZ}$ and $\mathrm{CA}$, were all nonsignificant and close to 0 ).

The composition of the soil cationic exchangeable pool which depends on the nature (organic/mineral) of the cationic exchanger, varied between the soil aggregate classes and sites.
Soil aggregate data agree with the hypothesis that $\mathrm{Mg}$ and $\mathrm{Ca}$ are more efficiently retained in the surface soil layers at $\mathrm{AZ}$ compared to CA. At AZ, fine aggregates $[0-50 \mu]$ rich in clay and Corg dominated in these soil layers and soil aggregates were likely to be more stable than at CA. At CA, the clay content was lower than at $\mathrm{AZ}$ and clay minerals at $\mathrm{CA}$ may be less reactive (presence of clays of the Fe-beidellite type, poorly reactive according to Robin et al. 2015). Although $\mathrm{Ca}$ and $\mathrm{Mg}$ cycled in the ecosystem through atmospheric deposition and litterfall were of the same magnitude as at AZ (Bedel et al. 2016) the [50-200 $\mu \mathrm{m}$ ] aggregates dominating at CA did not seem to efficiently retain the nutrient cations. In acid forest ecosystems, biological cycling is often of paramount importance as it allows to maintain nutrients in the topsoil. However, the nutrient recycling efficiency depends among other things on the nutrient retention capacity of soils: at CA, this capacity seems to be low in the topsoil and linked to the aggregation status. In our soils, we may thus consider that the study of soil aggregation helped to understand the nutrient cation availability to tree uptake. However, the reduced number of study sites does not allow to conclude on this hypothesis and further studies need to be done to gain insight on the link between soil aggregation and chemical fertility in forest ecosystems.

\section{Conclusion}

The investigation on soil aggregation was relevant to clarify the biogeochemical functioning of the two studied soils, which are described as the same soil type, but which nevertheless have different nutrient cation availability in the upper soil layers.

Our results highlighted that clay content in the $<2 \mathrm{~mm}$ class (fine earth) may be used as an indicator of soil aggregation status while clay mineralogy is helpful for understanding their stability. We showed that fine aggregates $[0-50 \mu]$ rich in clay and Corg dominated at AZ while the intermediate aggregate class [200-50 $\mu \mathrm{m}]$ poor in clay and in Corg dominated at CA. Lastly, our findings suggested that soil aggregation is more stable at AZ than at CA.

Even with the same atmospheric deposition rates and the same fluxes of nutrient cations in litterfall, the two compared ecosystems behaved very differently in terms of nutrient cation retention: when compared to AZ, the CA soil seems unable to fix nutrient cations. We suggested that the dominant aggregate class [200-50 $\mu \mathrm{m}]$ at CA, less stable and poor in reactive minerals and organic components, may mitigate the retention of nutrient cations by ion-exchange.

Though the results of this local case study do not enable to conclude at large scale, they agree with the hypothesis that soil aggregation plays an important role in nutrient cation availability to tree uptake. 
Acknowledgements We thank the ANR DST, the Région Lorraine, the Lhoist Group, the European Union via FEDER, the ONF, the LTSER France Zone Atelier Bassin Moselle and the Ministry of Research (through the $\mathrm{EC} 2 \mathrm{O}$ and OteLo programs) for funding. These sites belong to the SOERE F-ORE-T which is supported annually by Ecofor, Allenvi, and the French national research infrastructure ANAEE-F. Léa Bedel $\mathrm{PhD}$ thesis was granted by INRA and Région Lorraine. The UR BEF is supported by a grant overseen by the French National Research Agency (ANR) as part of the "Investissements d'Avenir" program (ANR-11LABX-0002-01, Lab of Excellence ARBRE).

Author contributions Conceptualization, investigation, data acquisition and analysis: Léa Bedel, Anne Poszwa, Arnaud Legout, Jacques Ranger Mineralogy: Emmanuelle Montarges-Pelletier, Mélanie Court

Writing — original draft: Léa Bedel, Arnaud Legout, Anne Poszwa, Jacques Ranger

Writing - review and editing: all co-authors

Project administration, supervision, funding acquisition: Jacques Ranger, Anne Poszwa, Arnaud Legout

\section{Funding information ANR DST \\ Région Lorraine \\ Lhoist Group \\ European Union (via FEDER)}

ONF

LTSER France Zone Atelier Bassin Moselle

French Ministry of Research (through the EC2O and OteLo programs) Ecofor

Allenvi

ANAEE-F

INRA

ANR-11-LABX-0002-01, Lab of Excellence ARBRE

Data availability The datasets generated during and/or analyzed during the current study are available from the corresponding author on reasonable request.

\section{Compliance with ethical standards}

Conflict of interest The authors declare that they have no conflict of interest.

\section{References}

Adesodun J, Adeyemi E, Oyegoke C (2007) Distribution of nutrient elements within water-stable aggregates of two tropical agroecological soils under different land uses. Soil Tillage Res 92:190197

Andreux F, Bruckert S, Correa A, Souchier B (1980) Sur une méthode de fractionnement physique et chimique des agrégats des sols : origines possibles de la matière organique des fractions obtenues. C R Acad Sci 381-384

Baize D, Girard MC (2008) Référentiel pédologique - Association française pour l'étude du sol (AFES). ISBN: 978-2-7592-0186-0. Edition Quae

Balesdent J (1996) The significance of organic separates to carbon dynamics and its modelling in some cultivated soils. Eur J Soil Sci 47: 485-493

Balesdent J, Petraud JP, Feller C (1991) Effets des ultrasons sur la distribution granulométrique des matières organiques des sols. Science du Sol (1984) 29:95-106
Balesdent J, Besnard E, Arrouays D, Chenu C (1998) The dynamics of carbon in particle-size fractions of soil in a forest-cultivation sequence. Plant Soil 201:49-57

Balesdent J, Chenu C, Balabane M (2000) Relationship of soil organic matter dynamics to physical protection and tillage. Soil Tillage Res 53:215-230

Bedel L, Poszwa A, van der Heijden G, Legout A, Aquilina L, Ranger J (2016) Unexpected calcium sources in deep soil layers in lowfertility forest soils identified by strontium isotopes (Lorraine plateau, eastern France). Geoderma 264:103-116

Berthelin J, Munier-Lamy C, Portal JM, Toutain F (1999) Physicochemical characterization, reactivity and biodegradability of soil natural organic matter. In: Baveye P, Block J-C, Goncharuk V (eds) Bioavailability of organic xenobiotics in the environment. NATO ASI series. Springer, Dordrecht, pp 251-296

Billings S (2006) Soil organic matter dynamics and land use change at a grassland/forest ecotone. Soil Biol Biochem 38:2934-2943

Bottinelli N, Capowiez Y, Ranger J (2014) Slow recovery of earthworm populations after heavy traffic in two forest soils in northern France. Appl Soil Ecol 73:130-133

Britzke D, da Silva L, Moterle D, dos Santos Rheinheimer D, Bortoluzzi E (2012) A study of potassium dynamics and mineralogy in soils from subtropical Brazilian lowlands. J Soils Sediments 12:185-197

Bronick CJ, Lal R (2005) Soil structure and management: a review. Geoderma 124:3-22

Capowiez Y, Boizard H, Bottinelli N, Ranger J (2015) Capacity of earthworms to restructure compacted soils, Workshop Regeneration of Compacted Forest Soils, Osnabrück, (Germany). 29 Octobre 2015

Carignan J, Hild P, Mevelle G, Morel J, Yeghicheyan D (2001) Routine analyses of trace elements in geological samples using flow injection and low pressure online liquid chromatography coupled to ICP-MS: a study of geochemical reference materials BR, DR-N, UB-N, ANG and GH. Geostand Newslett 25:187-198

Christensen BT (1992) Physical fractionation of soil and organic matter in primary particle size and density separates, advances in soil science. Springer, Berlin, pp 1-90

Ciesielski H, Sterckeman T, Santerne M, Willery JP (1997) Determination of cation exchange capacity and exchangeable cations in soils by means of cobalt hexamine trichloride. Effects of experimental conditions, 17. EDP Sciences, Les Ulis

Clark G, Sale T, Tang C (2010) Organic amendments initiate the formation and stabilization of macroaggregates in a high clay sodic soil. Aust J Soil Res 47:770-780

Fernández-Ugalde O, Barré P, Hubert F, Virto I, Girardin C, Ferrage E, Caner L, Chenu C (2013) Clay mineralogy differs qualitatively in aggregate-size classes: clay-mineral-based evidence for aggregate hierarchy in temperate soils. Eur J Soil Sci 64:410-422

Girard MC, Walter C, Rémy J-C, Berthelin J, Morel J-L (2011) Sols et environement. EAN13: 9782100549009. Dunod

Goutal N, Lamy F, Ranger J, Boivin P (2016) Structural damage and recovery determined by the colloidal constituents in two forest soils compacted by heavy traffic. Eur J Soil Sci 67:160-172

Greene-Kelly R (1953) Identification of Montmorillonoïds in clays. J Soil Sci 4:233-237

Hathaway J (1958) Clay Miner:15(8)

Haynes R, Naidu R (1998) Influence of lime, fertilizer and manure applications on soil organic matter content and soil physical conditions: a review. Nutr Cycl Agroecosyst 51:123-137

Hobbie SE, Reich PB, Oleksyn J, Ogdahl M, Zytkowiak R, Hale C, Karolewski P (2006) Tree species effects on decomposition and forest floor dynamics in a common garden. Ecology 87:2288-2297

Hoffmann U, Klemen E (1950) Loss of exchangeability of lithium ions in bentonite on heating. Z Anorg Allg Chem 262:95-99

Horn R (1990) Aggregate characterization as compared to soil bulk properties. Soil Tillage Res 17:265-289 
Jeanroy E (1983) Diagnostic des formes du fer dans les pédogénèses tempérées. Université Nancy, Nancy $168 \mathrm{p}+$ annexes pp

Jiménez JJ, Lorenz K, Lal R (2011) Organic carbon and nitrogen in soil particle-size aggregates under dry tropical forests from Guanacaste, Costa Rica - implications for within-site soil organic carbon stabilization. CATENA 86:178-191

Jolivet C, Arrouays D, Leveque J, Andreux F, Chenu C (2003) Organic carbon dynamics in soil particle-size separates of sandy Spodosols when forest is cleared for maize cropping. Eur J Soil Sci 54:257-268

Julien JL, Charlet L, Dambrine E, Delvaux B, Dufey J, Fardeau JC, Le Cadre E, Tessier D (2007) L'acidification des sols. chap 23. In: Girard MC, Walter C, Rémy JC, Berthelin J, Morel JL (eds) Sols et Environnement. Dunod Ed, Paris, pp 516-537

Kessler J, Chambraud A (1986) La météo de la France. JC Lattès, Paris $312 \mathrm{pp}$

Kuhn NJ, Armstrong EK, Ling AC, Connolly KL, Heckrath G (2012) Interrill erosion of carbon and phosphorus from conventionally and organically farmed Devon silt soils. CATENA 91:94-103

Kunze GW, Dixon JB (1986) Pretreatment for mineralogical analysis. In: Klute A (ed) Methods of soil analysis: Part 1-Physical and mineralogical methods. American Society of Agronomy, Madison, p 91100

Legout A, Hansson K, Van Der Heijden G, Laclau J-P, Augusto L, Ranger J (2014) Chemical fertility of forest soils: basic concepts. Revue Forestière Française LXVI:413-424

Leguédois S, Le Bissonnais Y (2004) Size fractions resulting from an aggregate stability test, Interrill detachment and transport. Earth Surf Process Landf 29:1117-1129

Mehra OP, Jackson ML (1960) Iron oxide removal from soils and clays by a dithionite-citrate system buffered with sodium bicarbonate. Clay Clay Miner 7:317-327

Moni C, Rumpel C, Virto I, Chabbi A, Chenu C (2010) Relative importance of sorption versus aggregation for organic matter storage in subsoil horizons of two contrasting soils. Eur J Soil Sci 61:958-969

Moni C, Derrien D, Hatton PJ, Zeller B, Kleber M (2012) Density fractions versus size separates: does physical fractionation isolate functional soil compartments? Biogeosciences 9:5181-5197

Oades JM (1984) Soil organic matter and structural stability: mechanisms and implications for management. Plant Soil 76(1-3):319-337

Oades J, Waters A (1991) Aggregate hierarchy in soils. Aust J Soil Res 29:815-828

Piccolo A, Pietramellara G, Mbagwu JSC (1997) Use of humic substances as soil conditioners to increase aggregate stability. Geoderma 75:267-277
Qin S, Hu C, He X, Dong W, Cui J, Wang Y (2010) Soil organic carbon, nutrients and relevant enzyme activities in particle-size fractions under conservational versus traditional agricultural management. Appl Soil Ecol 45:152-159

Reichert JM, Norton LD, Favaretto N, Huang C-h, Blume E (2009) Settling velocity, aggregate stability, and interrill erodibility of soils varying in clay mineralogy. Soil Sci Soc Am J 73:1369-1377

Robert M, Tessier D (1974) Méthode de préparation des argiles des sols pour des études minéralogiques. Annales Agronomiques 25:859-882

Robin V, Tertre E, Beaufort D, Regnault O, Sardini P, Descostes M (2015) Ion exchange reactions of major inorganic cations $(\mathrm{H}+, \mathrm{Na}+, \mathrm{Ca} 2+$, $\mathrm{Mg} 2+$ and $\mathrm{K}+$ ) on beidellite: experimental results and new thermodynamic database. Toward a better prediction of contaminant mobility in natural environments. Appl Geochem 59:74-84

Schmidt MWI, Torn MS, Abiven S, Dittmar T, Guggenberger G, Janssens IA, Kleber M, Kogel-Knabner I, Lehmann J, Manning DAC, Nannipieri P, Rasse DP, Weiner S, Trumbore SE (2011) Persistence of soil organic matter as an ecosystem property. Nature 478:49-56

Singer A (1994) Clay mineralogy as affecting dispersivity and crust formation in Aridisols, Transactions of the 15th World Congress of Soil Science. Acapulco, Mexico, pp 37-46

Six J, Bossuyt H, Degryze S, Denef K (2004) A history of research on the link between (micro)aggregates, soil biota, and soil organic matter dynamics. Soil Tillage Res 79:7-31

Stemmer M, Gerzabek MH, Kandeler E (1998) Organic matter and enzyme activity in particle-size fractions of soils obtained after lowenergy sonication. Soil Biol Biochem 30:9-17

Stern R, Ben-Hur M, Shainberg I (1991) Clay mineralogy effect on rain infiltration, seal formation and soil losses. Soil Sci 152(6):455-462

Tamura (1958) Identification of clays minerals from acid soils. J Soil Sci 9:141-147

von Lützow M, Kögel-Knabner I, Ekschmitt K, Flessa H, Guggenberger G, Matzner E, Marschner B (2007) SOM fractionation methods: relevance to functional pools and to stabilization mechanisms. Soil Biol Biochem 39:2183-2207

WRB., I.W.G (2014) World Reference Base for Soil Resources 2014. International soil classification system for naming soils and creating legends for soil maps. World soil resources reports no. 106. FAO, Rome

Zelazny L, Jardine P (1989) Surface reactions of aqueous aluminum species. In: Sposito G (ed) The environmental chemistry of aluminum. Lewis Publishers, New-York, p 147-184 